\title{
BOCTOK ORIENS
}

Восток. Афро-азиатские общества: история и современность. 2013-2023

ISSN 0869--1908

URL - $\underline{\text { http://vostokoriens.jes.su }}$

Все права защищены

Выпуск 6 Том . 2018

\section{Рецензия на: Cultural Genocide in Tibet: A Report. Dharamsala: The Tibet Policy Institute; The Department of Information and International Relations, Central Tibetan Administration (Drafting Committee: T. Samphel, B.D. Sonam, R. Dorjee, T. Desal)}

Кузьмин Сергей Львович

Институт востоковедения РАН

Российская Федерачия, Москва

Аннотация

Ключевые слова:

Дата публикации: 27.12.2018

Ссылка для цитирования:

Кузьмин С. Л. Рецензия на: Cultural Genocide in Tibet: A Report. Dharamsala: The Tibet Policy Institute; The Department of Information and International Relations, Central Tibetan Administration (Drafting Committee: T. Samphel, B.D. Sonam, R. Dorjee, T. Desal) // Восток. Афро-азиатские общества: история и современность. 2018. - Выпуск 6 C. 235-240 . URL: https://vostokoriens.jes.su/s086919080002988-31/. DOI: $10.31857 / \mathrm{S} 086919080002988-3$ 
1. Неронов Р.М. Социально-классовая политика китайского руководства и некоторые ее особенности в национальных районах 1971-1976 гг. Маоизм и национальный вопрос. Материалы Международного научного симпозиума. УланБатор, 1980. 220 с.

2. Декларация Организации Объединенных Наций о правах коренных народов. http://www.un.org/esa/socdev/unpfii/documents/DRIPS_ru.pdf.

3. International Commission of Jurists Report «The Question of Tibet and the Rule of Law». Geneva. http://www.tibetpolicy.eu/wp-content/uploads/173 1959-1960 TheQuestion-of-Tibet-and-the-Rule-of-Law.pdf. 


\section{Review of the book: Cultural Genocide in Tibet: A Report. Dharamsala: The Tibet Policy Institute; The Department of Information and International Relations, Central Tibetan Administration (Drafting Committee: T. Samphel, B.D. Sonam, R. Dorjee, T. Desal)}

\section{Sergius Kuzmin}

Institute of Oriental Studies, Russian Academy of Sciences

Russian Federation, Moscow

Abstract

Keywords:

Date of publication: 27.12 .2018

Citation link:

Kuzmin S. Review of the book: Cultural Genocide in Tibet: A Report. Dharamsala: The Tibet Policy Institute; The Department of Information and International Relations, Central Tibetan Administration (Drafting Committee: T. Samphel, B.D. Sonam, R. Dorjee, T. Desal) // Vostok. Afro-aziatskie obshchestva: istoriia i sovremennost. - 2018. - Issue 6 C. 235-240 . URL: https://vostokoriens.jes.su/s086919080002988-3-1/. DOI: $10.31857 / \mathrm{S} 086919080002988-3$

Код пользователя: 0; Дата выгрузки: 26.04.2023; URL - http://vostokoriens.jes.su/s086919080002988-3-1/ Bce права защищены. 